\title{
Effluent flux prediction in variably saturated soil zones within a septic tank - soil absorption trench
}

Cara D. Beal ${ }^{A}$, Ted Gardner ${ }^{A}$, David R. Rassam $^{C}$, Alison M. Vieritz ${ }^{B}$, Neal W. Menzies ${ }^{A}$

${ }^{A}$ School of Land \& Food Sciences, University of Queensland; and Coastal CRC, Indooroopilly, Qld email: c.beal@uq.edu.au

${ }^{B}$ Qld Department of Natural Resources, Mines \& Water, Indooroopilly, Qld

${ }^{C}$ CSIRO Land and Water, Indooroopilly, Qld 4068, Australia

\section{Abstract}

The treatment and hydraulic mechanisms in a septic tank - soil absorption system (SAS) are highly influenced by the clogging layer or biomat zone which develops on bottom and lower sidewall surfaces within the trench. Flow rates through the biomat and sub-biomat zones are governed largely by the biomat hydraulic properties (resistance and hydraulic conductivity) and the unsaturated hydraulic conductivity of the underlying soil. One dimensional and two dimensional models were used to investigate the relative importance of sidewall and vertical flow rates and pathways in SAS. Results of one-dimensional modelling show that several orders of magnitude variation in saturated hydraulic conductivity $(K s)$ reduce to a one order of magnitude variation in long-term flow rates.

To increase the reliability of prediction of septic trench hydrology, HYDRUS-2D was used to model two dimensional flow. In the permeable soils, under high trench loading, effluent preferentially flowed in the upper region of the trench where no resistant biomat was present (the exfiltration zone). In comparison, flow was more evenly partitioned between the biomat zones and the exfiltration zones of the low permeable soil. An increase in effluent infiltration corresponded with a greater availability of exfiltration zone, rather than a lower resistance of 
biomat. Results of modelling simulations demonstrated the important role that a permeable A horizon may play in limiting surface surcharge of effluent under high trench hydraulic loading.

\section{Additional keywords}

Biomat zone, septic system, unsaturated flow, HYDRUS -2D, modelling, on-site wastewater

\section{Introduction}

Well-managed on-site wastewater treatment and dispersal systems are recognised as “..a costeffective and long-term option for meeting public health and water quality goals.." by the USEPA (1997). Despite this, the hydrology of the septic tank-soil absorption system (SAS), the most common form of on-site system in both Australia and the United States, remains inadequately understood. There is a lack of substantiated knowledge of the key processes of SAS, particularly in Australian soils. Poorly performing systems have been linked to elevated effluent pollutant loads in receiving waters (Whitehead and Geary 2000; Bopp et al. 2003; Ahmed et al. 2005). The effluent pollutants of primary concern are nitrate and pathogens (e.g. faecal coliforms). Beal et al. (2005) summarised a number of studies investigating the off-site export of effluent pollutants in non-sewered areas. Knowledge of the critical hydraulic processes that occur in SAS are essential in assessing whether continued use of SAS is viable and sustainable.

A SAS commonly operates by primary treatment of effluent in a septic tank followed by infiltration into the subsoil via a series of trenches (Fig. 1). The treatment and hydraulic mechanisms in a SAS are complex and have been shown to be highly influenced by the clogging layer or biomat zone which develops on bottom and lower sidewall surfaces within 
the trench (Bouma 1975; Siegrist 1987) (Fig.1 ). The biomat zone, when fully developed, is highly resistant and thus regulates flow into the underlying soil. The greater the resistance, the lower the flow rate through the biomat. This can create conditions where effluent builds up above the biomat while the underlying soil remains unsaturated (Kristiansen 1981; Beach et al. 2005). Under standard hydraulic loadings (e.g. 5 to $30 \mathrm{~mm} /$ day), the typical flow pathway for effluent in SAS is through the bottom and sidewall biomat zones. Flow rates through these biomat zones are governed largely by the biomat hydraulic properties (resistance and hydraulic conductivity) and the unsaturated hydraulic conductivity of the underlying soil (Bouma 1975; Beal et al. 2006). A ‘feedback loop’ occurs under steady state conditions, when the matric potentials that develop under the biomat zone create a gradient through the biomat and an unsaturated hydraulic conductivity in the sub-biomat zone, that results in equal flux through both layers (Hillel 1980).

Fig. 1

In addition to regulating effluent flow in a SAS, the biomat zone plays an important role in maintaining unsaturated conditions in the underlying soil. The unsaturated soil beneath the biomat represents a critical 'effluent treatment zone’ (Fig. 1). High removal rates of effluent pollutants (eg. pathogens, nutrients, biochemical oxygen demand (BOD) and total suspended solids (TSS)) in SAS are correlated with the presence of at least 0.6 to $0.9 \mathrm{~m}$ of unsaturated zone underlying a well developed biomat zone (Magdoff et al. 1974; Wilhelm et al. 1994; Ptacek 1998; van Cuyk et al. 2004). The removal efficiencies of the biomat and unsaturated zones (Fig 2) show that key SAS pollutants are reduced to $<10 \%$ of their original concentration, with the exception of nitrate. Nitrate is generated from nitrification of 
ammonium, which is present in high concentrations ( 40 to $60 \mathrm{mg} / \mathrm{L}$ ) in the septic tank effluent (Beal et al. 2005).

Fig. 2

Research indicates that the optimal effluent flow pathway to promote treatment of effluent pollutants is the vertical travel through a resistant biomat zone, where the hydraulic retention time and contact with the soil matrix is maximised (Siegrist et al. 2000). However, in reality, effluent entering a trench can infiltrate into the soil either through the bottom or sidewalls and may by-pass the effluent treatment zone altogether in certain circumstances, such as unusually high loading. In situations of excessive trench loading, such as in heavy or prolonged rainfall or high household water use, effluent may preferentially infiltrate into the area of upper sidewall that has no impedance from a biomat zone (the exfiltration zone). The exfiltration zone (represented by $\mathrm{Q}_{\mathrm{EZ}}$ in Fig. 3) is hypothesised to be an important absorption pathway for effluent under situations of peak loading.

There are a limited number of studies modelling unsaturated flow in SAS (Janni et al. 1980; Hansen and Mansell 1986; e.g. Beach and McCray 2003; Radcliffe et al. 2005), but the specific partitioning of biomat zone and non-biomat zone flow in SAS is not widely reported. A study by Brouwer et al. (1979) found flow through the sidewall to be greater than bottom flow in some duplex soils in Victoria. This conclusion was drawn from field measurement of matric potentials below and adjacent to trenches, and the ponded height in the trenches. The infiltration rate through the sidewalls was calculated at $35 \mathrm{~mm} /$ day, but it is not clear if sidewall flow was solely through the biomat zone. McGauhney and Winneberger (1964) reported greater sidewall water flow in sands compared with finer-grained soils. Beach and 
McCray (2003) used HYDRUS-2D to predict unsaturated flow within SAS, and described a strong relationship between the biomat zone hydraulic properties, and the steady-state (longterm) infiltration rates within the unsaturated zone. However, the model assumed that all flow occurred through either the trench bottom or trench sidewall biomat layer, thus precluding the opportunity to predict flow dynamics for the remainder of the trench sidewall.

Despite the growing body of research on SAS, the relationship between how a SAS performs hydraulically and how this is interlinked with treatment efficacy is not well understood, particularly with respect to different soil types and loading rates into the trenches. The main objectives of the research reported in this paper were to predict the flow pathways of effluent under atypical trench loading regimes, and to explore the mechanisms leading to trench hydraulic failure. One dimensional and two dimensional models were used to investigate the relative importance of sidewall and vertical flow rates and pathways in SAS under extreme hydraulic loading conditions.

\section{Materials and methods}

\section{Soils}

Hydraulic properties measured on undisturbed cores from four soils were obtained from the literature (Table 1). The first three of these soils were chosen as they generally represent the type of permeable, well-structured soils that are suitable for SAS (Verburg et al. 2001). The final soil was chosen to represent a soil type that is unsuitable for SAS, based on the high clay content and low permeability (Talsma 1983). This soil was chosen to provide a contrast in flow 
pathways between different soil textures. Additionally, many of the soils which occur in nonsewered areas across Australia are poorly draining, clay soils (McKenzie et al. 2004).

\section{Table 1.}

\section{One-dimensional modelling}

“Flux for Septic Trenches” (FLUX), a spreadsheet model developed by the authors, was used to predict one-dimensional steady-state fluxes for various biomat resistances. The steady-state flux through the biomat zone was calculated using the mathematical relationship, as described by Bouma (1975), between saturated biomat zone and underlying unsaturated soil zone:

$$
Q_{b}=Q_{u}=K_{b}\left(\frac{d H}{d Z}\right)_{b}=K_{u}\left(\frac{d H}{d Z}\right)_{u}
$$

where $Q_{b}$ is the steady-state flux through the biomat (m/day), $Q_{u}$ is the steady-state flow through the unsaturated zone below the biomat (m/day), $K_{b}$ is the biomat hydraulic conductivity $(\mathrm{m} / \mathrm{d}),(d H / d Z)_{b}$ the biomat hydraulic gradient, $K_{u}$ the unsaturated hydraulic conductivity (m/day) and $(d H / d Z)_{u}$ the hydraulic gradient of the unsaturated sub-biomat zone. The value $\mathrm{Q} b=\mathrm{Q} u$ (Eqn 1) was solved as a simultaneous equation for a range of biomat resistances.

Campbell's (1974) model was used to calculate the unsaturated hydraulic conductivity of the sub-biomat zone, using the measured near-saturated hydraulic conductivity (Ks) values (Talsma 1983; Verburg et al. 2001) as the matching $\mathrm{K}$ factor. The Campbell model is represented as:

$$
K=K_{S}\left(\frac{\psi e}{\psi}\right)^{2+3 / b}
$$


where $\Psi_{\mathrm{e}}$ is the air-entry potential of the soil $(\mathrm{m})$, and $b$ is the slope of the $\Psi(\theta)$ relationship (Campbell 1974).

Results were checked by running the same input parameters in SWIM v1.0 (Ross 1990). Biomat resistances used in the model encompassed a range of values reported in the literature (Magdoff and Bouma 1974; Beach and McCray 2003). The FLUX model, in accordance with assumptions held for Eqn 1, assumed that all flow was steady-state with a unit gradient, and flow occurred in a one-directional manner, vertically through the biomat zone. A relatively deep and homogenous soil profile was assumed. Ponded water height was set at $0.25 \mathrm{~m}$ and the biomat thickness was assumed to be $0.02 \mathrm{~m}$.

\section{Two-dimensional modelling}

HYDRUS-2D, a two-dimensional variably saturated flow model (Simunek et al. 1999), was used to model flow through the bottom and sidewall areas of a SAS. HYDRUS-2D uses the Richard's (1938) equation as the governing equation for water flow. The soil water retention curve, $\theta(\Psi)$, is described using the closed-form equation of van Genuchten (1980):

$$
\theta(\psi)=\theta_{r}+\left[\left(\theta_{S}-\theta_{r}\right) /\left(1+(\alpha|\psi|)^{n}\right)^{(m)}\right]
$$

The unsaturated soil hydraulic conductivity function, $K(\Psi)$, is described by combining the van Genuchten equation with the pore-size distribution model of Mualem (1976):

$$
K(\psi)=K_{S} S_{e}^{l}\left[1-\left(1-S_{e}^{1 / m}\right)^{m}\right]^{2}
$$


where $\theta$ is the volumetric water content $\left(\mathrm{m}^{3} / \mathrm{m}^{3}\right), \Psi$ is the pressure head $(\mathrm{m}), \alpha, n, m(=1-1 / n)$ and $l(=0.5)$ are empirical parameters, $\left.\mathrm{S}_{\mathrm{e}}=\left(\theta-\theta_{\mathrm{r}}\right) / \theta_{\mathrm{s}}-\theta_{\mathrm{r}}\right)$ is the degree of saturation, $\theta_{\mathrm{r}}$ is the residual water content, and $\theta_{\mathrm{s}}$ is the saturated water content.

\section{Table 2.}

Four soils, as described in Table 1, were used in the two dimensional modelling (Table 2). The input parameters for the Verburg et al. (2001) soils were derived from the soil hydraulic properties reported in the literature and by the pedotransfer function model ROSETTA (Schaap 2001) (Table 2). Optimisation of input parameters for the Yellow Kurosol was done by minimising the squared differences between the measured moisture retention data reported (Talsma 1983) and the water contents and $\mathrm{K}$ values which were estimated using equations 3 and 4. There are few specifically measured biomat zone saturated hydraulic conductivities in the literature; they are usually estimated or derived from Eqn. 1 and 2. The saturated hydraulic conductivities for the biomat zone fall within the range reported by previous researchers (Bouma 1975; Beach and McCray 2003). As there are no reported values for biomat water retention characteristics, the parameters $\theta_{\mathrm{r}}, \theta_{\mathrm{s}}$, and $n$ were assumed to be similar to a silty clay soil as discussed by Beach and McCray (2003).

The modelling domain was represented by half a trench system, with an assumption of soil homogeneity and symmetry in the hydraulic behaviour of the trench (Fig. 3). Flow through the biomat zones was partitioned between vertical flow through the bottom biomat zone $\left(Q_{b}\right)$, and 
horizontal flow through sidewall biomat zone $\left(Q_{s w}\right)$ (Fig. 3). Horizontal flow through the exfiltration zone (biomat-free sidewalls) of the trench is denoted as $Q_{E Z}$ (Fig. 3).

\section{Fig 3.}

A pressure head initial condition of field capacity (approximately $-0.2 \mathrm{~m}$ to $-0.3 \mathrm{~m}$ for sandy soils and approximately $-2.0 \mathrm{~m}$ to $-3.0 \mathrm{~m}$ for light clays / clays) was used. As the steady-state flow regimes were being examined, the initial conditions were not a critical consideration as they have no influence on the final modelling outcomes. A constant pressure head (m) boundary condition was assigned for all runs for each of the three scenarios. The pressure head was maintained at hydrostatic equilibrium for all scenario runs. The value of the pressure head varied between $0.15 \mathrm{~m}$ and $0.35 \mathrm{~m}$, depending on which scenario was being modelled (Table 3).

\section{Table 3.}

\section{Results and Discussion}

\section{One-dimensional modelling}

The predicted effect on flow rates from increasing biomat resistance $\left(R_{b}\right)$ is shown in Fig. 4. The steady state flow rate value $(Q)$ represents the long-term acceptance rate (LTAR) of effluent into any given soil. The LTAR is a key parameter used in the Australian and New Zealand Standards (Standards Australia and Standards New Zealand 2000) to calculate the soil surface area and length of trench required to avoid hydraulic surcharge. As these results are calculated from a one-dimensional model, LTAR can be estimated for any combination of $R_{b}$ 
and soil hydraulic properties. As the $R_{b}$ of the biomat zone increased, the infiltration rate through the biomat zone decreased and soil moisture tensions immediately below the biomat zone increased (i.e. the soil became “drier”). Results are consistent with other similar studies (Bouma 1975; Kristiansen 1981; Siegrist and Boyle 1987) in that a 2 to 3 order of magnitude variation in saturated hydraulic conductivity between the soils reduced to a one order of magnitude variation in LTAR. Biomat zones of low resistance (e.g. $R_{b}=10$ days) can have a marked effect on flow rates in sandy soils (e.g. Red Dermosol and Podsol) compared to clay soils (e.g. Yellow Kurosol) which have an inherently low Ks (Fig. 4).

\section{Fig. 4}

This may be directly attributed to the moisture retention characteristics of sandy, coarsegrained soils as they undergo substantial pore water draining at high matric potentials (i.e. low soil tensions) and consequently the conductance of water through the soil will be reduced as the larger pores drain (as flow is proportional to the fourth power of the pore radius). Therefore, as the sub-biomat soil becomes more unsaturated due to increasing biomat resistance, flow rates in this unsaturated zone will be substantially reduced. Conversely, in finer-textured soils of low saturated hydraulic conductivities (e.g. $<0.01 \mathrm{~m} /$ day), biomats of low resistance will not markedly affect the underlying soil hydraulic properties. For example, flow rates in the Yellow Kurosol which has a low hydraulic conductivity (0.014 m/day) only began to be noticeably affected by a biomat of $R_{b} 60$ days (Fig. 4). Beach and McCray (2003) also found that (modelled) water flow through a biomat was influenced to a greater extent in sandy soils compared with silt soils. They reported that a decrease in $\mathrm{K}_{b}$ by a factor of 2 to 3 resulted in a corresponding increase in trench pond height up to a factor of five in sandy soils. 
The same degree of increase in pond height was not observed for the silt soils under the same $\mathrm{K}_{b}$ increases, suggesting that the biomat zone is not markedly affecting flow in these soils (Beach and McCray 2003).

\section{Two-dimensional modelling}

The partitioning of flow between the biomat zones (sidewall and bottom) and exfiltration zone for each scenario was modelled using HYDRUS-2D. The partitioning of flow within SAS located in two different soil textures were compared (Fig 5.). Flow in the Yellow Kurosol was much more evenly partitioned between the biomat zones and the exfiltration zone compared with the more permeable Red Dermosol. With the exception of run 1 for scenario 3 (sidewall biomat height $=0 \mathrm{~m}$, Table 3 ), the biomat zones were as important as the exfiltration zone in infiltrating the ponded water in the Kurosol (Fig. 5). Note that in the case of run 1, the absence of sidewall biomat would be likely to occur in the field only at the very early stages of biomat development.

\section{Fig. 5.}

Conversely, flow through the exfiltration zone in the Red Dermosol was predominant, ranging from 82 to $96 \%$ of overall flow. In permeable soils, the hydraulic conductivity of the nearsaturated exfiltration zone is likely to be higher than the saturated hydraulic conductivity of the sidewall biomat zone, therefore effluent will preferentially flow through the exfiltration zone during periods when ponded effluent rises above the sidewall biomat zone. Thus, under unusually high loading, the flow of effluent in permeable soils is by way of the path of least resistance - through the exfiltration zone. In soils where the saturated hydraulic conductivity 
does not differ significantly from the biomat zone hydraulic conductivity, effluent will not preferentially flow through the exfiltration zone. Beach and McCray (2003) reported twodimensional flow through biomat sidewalls was greater in sandy soils than in a silt soils. In their study, water content distribution in sandy soils was uneven across the modelled domain, with a preferential flow through the sidewall biomat (sidewall infiltration above the biomat was not included in the modelling). They argued that preferential flow through the sidewall biomat was the result of the higher Ks of the sidewall. Conversely, the water distribution was much more uniform in the silt soil, suggesting, (as also observed in this experiment (Fig. 5)), a more even distribution of water flow occurred through the bottom and sidewall biomats compared with the sand (Beach and McCray 2003).

The total flux of effluent $(\mathrm{L} / \mathrm{m} /$ day) infiltrating through the trench area (biomat + exfiltration zone) was also calculated using HYDRUS-2D (Fig. 6). Daily volumes of up to $400 \mathrm{~L}$ of effluent per metre of trench were predicted to flow through the trench (bottom and sidewalls) in the Red Dermosol (Ks $0.98 \mathrm{~m} /$ day) with a ponded water height of $0.35 \mathrm{~m}$ (Fig 6a). About $90 \%$ of this will be through the exfiltration zone (Fig 5.). In comparison, total daily flux of effluent predicted to flow through the trench in the Yellow Kurosol (Ks 0.014 m/day) was 9 L per metre of trench ( for the same water height $(0.35 \mathrm{~m})$ with only about $50 \%$ flow through the exfiltration zone (Fig. 5). The total flow of effluent did not appreciably change with any combination of water height and biomat zone scenarios for the Yellow Kurosol (Fig. 6 and Fig. 7). This is a function of the similarity between the soil and biomat $K s$, and the resultant low hydraulic gradients across the biomat. The Semiaquic Podosol (Ks $1.5 \mathrm{~m} /$ day) was predicted to generate the greatest volume of flow of over $\sim 700 \mathrm{~L} / \mathrm{m} /$ day at ponded water height of $0.35 \mathrm{~m}$. 
The equivalent LTAR at a water height of $0.35 \mathrm{~m}$ for the permeable soils ranged from $0.68 \mathrm{~m} / \mathrm{d}$ to $1.6 \mathrm{~m} / \mathrm{d}$ (Fig. 6a). As expected, these values are not typical of LTAR reported for standard hydraulic flow regimes in SAS of $\sim 0.01 \mathrm{~m} / \mathrm{d}$ to $0.05 \mathrm{~m} / \mathrm{d}$ (Bouma 1975; Sherlock et al. 2002; Finch et al. 2005; Radcliffe et al. 2005) as they represent atypical fluxes under extreme hydraulic loading. Measured infiltration rates for sidewall exfiltration under high trench loadings in the field have seldom been reported, though Dix (2001) reported sidewall fluxes in a medium and fine sands to range from 130 to $260 \mathrm{~L} / \mathrm{m} / \mathrm{d}$ (dimensions of trench not given). Infiltration rates were measured immediately after filling the trenches to their maximum volumetric capacity, so the ponded heights were not maintained for any length of time (Dix 2001).

The time taken for simulations to reach steady-state for all scenarios was an average of $<2$ days (maximum 10 days). In permeable soils, assuming a properly functioning SAS, ponded water heights of $0.35 \mathrm{~m}$ remaining constant for $>2$ days maybe unrealistic, as extreme hydraulic loading conditions are expected to be more transient (e.g. intense, short rainfall events or 'one-off' high household usage). This is particularly true given the capacity of the exfiltration zone to discharge water at high volumetric fluxes. However, the modelling demonstrates the importance of the exfiltration zone in providing buffer a against extreme loading events. Thus, hydraulic failure, i.e. surface surcharging of effluent, may be substantially reduced in permeable soils, where an exfiltration zone is present.

\section{Fig. 6.}


As sidewall biomat zone increased there was a concomitant decrease in total effluent flows through the system (Fig. 6). This is expected, as the area of exfiltration zone available became considerably reduced as sidewall biomat increased up the trench walls. Increasing sidewall biomat occurs as the equilibrium level of effluent in the trench gradually rises over time, thus exposing more and more of the sidewall to "clogging agents" (organic matter and suspended solids) contained in the ponded effluent (Siegrist and Boyle 1987). Rising trench water level usually result from changes (increases) in bottom biomat zone resistance. Changes to equilibrium bottom biomat resistance may be triggered by several factors including a deterioration in effluent quality (more clogging agents contained in effluent), and episodes of solids carry-over from the septic tank (Siegrist et al. 2000). As the sidewall biomat zone rises up the trench sides, the ratio of permeable (native soil) to low-permeable (biomat) sidewall decreases with a consequent decrease in total effluent flow through the system under extreme hydraulic loading. Under field conditions, this situation would be likely to cause surface surcharging of effluent.

\section{Fig 7}

Effluent flows through the biomat decreased gradually as $\mathrm{R}_{b}$ increased (Fig. 7a). However, when considering all available infiltrative surfaces of a trench, no appreciable decrease in total effluent flows after $\mathrm{R}_{b}>5$ days was observed (Fig. 7b). That is, regardless of biomat resistance, the exfiltration zone in the three permeable soils dominated the infiltration rate into the surrounding soil, thus total effluent flux remained unresponsive to increases in $R_{b}$. In comparison, when only considering vertical flow through the biomat (Fig. 4), $\mathrm{R}_{b}$ clearly reduced flows. Other studies also indicate a much greater response of flow rates to $\mathrm{R}_{b}$ (Janni et 
al. 1980; Hansen and Mansell 1986; Beach and McCray 2003), though these models did not consider the trench walls above the biomat. The negligible change to overall effluent flow rates with decreasing $\mathrm{R}_{b}$ further illustrates the important role that a permeable A horizon may play in limiting surface surcharge of effluent in wet conditions.

As discussed earlier, effluent treatment is greatly enhanced by prolonged hydraulic retention times in unsaturated soil (van Cuyk et al. 2001). Van Cuyk et al. (2004) estimated a travel time of 5 to 20 days for effluent to infiltrate $0.6 \mathrm{~m}$ through an undisturbed soil core. This travel time was sufficient for a 2 to 3 log reduction of virus and bacteria populations (van Cuyk et al. 2004). In simulations of high trench loading, the exfiltration zone pathway in a soil of high saturated conductivity (e.g. Semiaquic Podosol) became near-saturated (0 to $-0.2 \mathrm{~m}$ ) resulting in higher effluent velocities through this region, compared with the biomat zones (Fig 8). Conversely, the soil moisture potentials and effluent velocities are more comparable between the biomat and exfiltration zones in the Yellow Kurosol (Fig. 9). Although the velocities and effluent fluxes predicted from HYDRUS-2D are likely to be slightly higher than may occur in the field (for reasons discussed earlier), they would still be expected to be substantially greater than would occur through the biomat zone. Given this, and the near saturated soil matrix in the exfiltration zone (Figs. 8 and 9), an adequate level of treatment (i.e. BOD, total suspended solids, pathogens and phosphorus reduction) may not be attained during high trench loading into highly permeable soils, particularly if a shallow water table exists. However, under extreme hydraulic loading conditions, without the presence of a permeable exfiltration zone to discharge excess water into the surrounding soil, surface surcharge may occur. On balance, and given that retaining effluent below the soil is critical for limiting pathogen export (van Cuyk et 
al. 2001), a short passage of near-saturated flow (assuming subsequent unsaturated flow prior to exposure to groundwater) may be a more favourable option in wet conditions than surface surcharging and subsequent export of effluent via stormwater run-off.

\section{Fig. 8.}

Fig. 9.

\section{Conclusion}

The default hydraulic mechanism by which effluent infiltrates through an absorption trench under normal loading rate and climatic conditions is through the bottom and sidewall biomat zones. However, under atypical, extreme hydraulic loading, data presented in here indicates that the majority of flow occurs preferentially through the trench sidewalls, above the biomat zone. This conclusion is drawn from the following observations from the modelled data:

i) water heights (scenario 1) and sidewall biomat height (scenario 3) influenced infiltration rates and total volume of effluent more markedly than biomat resistance (scenario 2);

ii) the common factor in both scenarios 1 and 3 was the availability of exfiltration zone able to be utilised - the data demonstrates that an increase in effluent infiltration corresponded with a greater availability of exfiltration zone, rather than a lower resistance of biomat (although the early stages of biomat development did result in a reduction in flows); 
iii) although the exfiltration zone appears to provide an effective hydraulic pathway during high trench loading, effluent treatment efficiency may be compromised in these conditions.

The modelling considered atypical static ponded heights under steady-state flow. In reality, a more dynamic system may occur, where biomat resistance decreases and ponded effluent heights in the trench concomitantly increase. However, the objective was to explore pathways and flow rates under extreme hydraulic loadings as little is known about this scenario, yet this is the condition that would occur before a surface surcharge event. The critical role of the exfiltration zone may help explain why hydraulic failure of SAS in permeable soils are reported rarely, despite evidence that the biomat zone reduces flows in permeable soils to a greater extent than less permeable soils. A key assumption in the AS/NZS 1547 Standard (Standards Australia and Standards New Zealand 2000) is that in "permeable and freely draining soils, absorption through the bottom area of trenches and beds is the significant absorption mechanism”. Results of modelling simulations reported here suggest that this is not necessarily the case, and that the importance of sidewall flow in limiting the incidence of hydraulic failure in permeable soils has been underestimated.

\section{References}

Ahmed W, Neller R, Katouli M (2005) Evidence of septic system failure determined by a bacterial biochemical fingerprinting method. Journal of Applied Microbiology 98, 910-920.

Beach D, McCray J, Lowe K, Siegrist R (2005) Temporal changes in hydraulic conductivity of sand porous media biofilters during wastewater infiltration due to biomat formation. Journal of Hydrology 311, 230-243. 
Beach DNH, McCray JE (2003) Numerical modeling of unsaturated flow in wastewater soil absorption systems. Ground Water Monitoring and Remediation 23, 64-72.

Beal CD, Gardner EA, Menzies NW (2005) Process, performance and pollution potential: A review of septic tank - soil absorption systems. Australian Journal of Soil Research 43, 781- 802.

Beal CD, Gardner T, Kirchhof G, Menzies NW (2006) Long term flow rates and biomat zone hydrology in soil columns receiving septic tank effluent. Water Research. In Press.

Bopp DJ, Sauders BD, et al. (2003) Detection, isolation and molecular subtyping of Escherichia coli O157:H7 and Campylobacter jejuni associated with a large waterborne outbreak. Journal of Clinical Microbiology 41, 174-180.

Bouma J (1975) Unsaturated flow during soil treatment of septic tank effluent. Journal of Environmental Engineering (ASCE) 101, 967-983.

Brouwer J, Willatt ST, van der Graaff R (1979) The hydrology of on-site septic tank effluent disposal on a yellow duplex soil. In 'Hydrology and Water Resources Symposium, 10-12 Sept 1979, Perth'. (IEAust, ACT)

Campbell GS (1974) A simple method for determining unsaturated conductivity from moisture retention data. Soil Science 117, 311-314.

Dix SP (2001) Affects of sand texture on sidewall absorption of septic tank effluent. In ' Proc. of Ninth Nat. Symp. Ind. and Small Comm. Sewage Sys.' (Ed. K Mancl) pp. 159-170. (ASAE; St Joseph; USA)

Finch SD, West LT, Radcliffe DE, Hufstetler EV (2005) Hydraulic properties of drainfield trench biomats formed in Georgia soils. In 'National Onsite Wastewater Recycling Association 14th Annual Technical Education Conference \& Exposition, Oct 10-13th'. (NOWRA)

Hansen EC, Mansell RS (1986) Simulated unsaturated-saturated water flow from a septic tank drain to groundwater. Soil and Crop Science Society of Florida 45, 21-29.

Hillel D (1980) 'Applications of soil physics.' (Academic Press, Inc.)

Isbell RF (1998) 'The Australian Soil Classification.' (CSIRO Publishing, Collingwood Victoria, Australia. 143p)

Janni KA, Nye JC, Jones DD, Krutz GW, Yahner JE (1980) Finite element analysis of effluent flow from subsurface sewage disposal fields. Transactions of the ASAE 23, 336-342.

Kristiansen R (1981) Sand-filter trenches for purification of septic tank effluent: I. The clogging mechanism and soil physical environment. Journal of Environmental Quality 10, 353-357.

Magdoff FR, Bouma J (1974) The development of soil clogging in sands leached with septic tank effluent. Proceedings of the National Homesewage Disposal Symposium, 1974 . 37-47.

Magdoff FR, Bouma J, Keeney DR (1974) Columns representing mound-type disposal systems for septic tank effluent: I. Soil-water and gas relations. Journal of Environmental Quality 3, 223-228. 
McGauhney PH, Winneberger JH (1964) Studies of the failure of septic tank percolation systems. Journal of Water Pollution Control Federation 36, 593-606.

McKenzie N, Jacquier D, Isbell R, Brown K (2004) 'Australian soils and landscapes: an illustrated compendium.' (CSIRO Publishing, Vic., Aust.)

Mualem Y (1976) A new model for predicting the hydraulic conductivity of unsaturated porous media. Water Resources Research 12, 513-522.

Ptacek CJ (1998) Geochemistry of a septic-system plume in a coastal barrier bar, Point Pelee, Ontario, Canada. Journal of Contaminant Hydrology 33, 293-312.

Radcliffe DE, West LT, Singer J (2005) Gravel effect on wastewater infiltration from septic system trenches. Soil Science Society of America Journal 69, 1217-1224.

Richards SJ (1938) Soil moisture content calculations from capillary tension records. Soil Science Society of America Proceedings 3, 57-64.

Ross PJ (1990) 'SWIM: A simulation model for soil water infiltration and movement.' CSIRO Aust. Division of Soils, Townsville.

Schaap MG (2001) 'ROSETTA.' Version 1.2, US Salinity Laboratory ARS-USDA, Riverside CA.

Sherlock MD, McDonnell JJ, Curry DS, Zumbuhl AT (2002) Physical controls on septic leachate movement in the vadose zone at hillslope scale, Putnam County, New York, USA. Hydrological Processes 16, 2559-2575.

Siegrist R (1987) Soil clogging during subsurface wastewater infiltration as affected by effluent composition and loading rate. Journal of Environmental Quality 16, 181-187.

Siegrist R, Boyle WC (1987) Wastewater-induced soil clogging development. Journal of Environmental Engineering 113, 550-566.

Siegrist R, Tyler EJ, Jenssen PD (2000) 'Design and performance of onsite wastewater soil absorption systems.' National Research Needs Conference Proceedings: Risk Based Decision Making for Onsite Wastewater Treatment. EPRI Palo Alto, CA, U.S. EPA and National Decentralized Water Resources Capacity Development Project: 20011101446.

Simunek J, Sejna M, van Gunuchten MT (1999) 'The HYDRUS-2D software package for simulating water flow and solute transport in two-dimensional variably saturated media.' Version 2. IGWMC7000-9938. International Groundwater Modeling Center, Colorado School of Mines, Golden, CO.

Standards Australia, Standards New Zealand (2000) 'AS/NZS 1547:2000 On-site domestic wastewater management.' (Jointly published by Standards Australia International Ltd, NSW and Standards New Zealand, Wellington)

Talsma T (1983) Soils of the Cotter catchment area, A.C.T.: distribution, chemical and physical properties. Australian Journal of Soil Research 21, 241-255.

USDA and NRCS (2006) 'Keys to soil taxonomy.' (United States Department of Agriculture and Natural Resources Conservation Service, Washington D.C, USA) 
USEPA (1997) 'Response to Congress On Use of Decentralized Wastewater Treatment Systems. USEPA publication EPA/832/R-97/001b. U.S. Environmental Protection Agency, Office of Water, Washington, DC.'

van Cuyk S, Siegrist R, Logan A, Masson S, Fischer E, Figueroa L (2001) Hydraulic and purification behaviours and their interactions during wastewater treatment in soil infiltration systems. Water Research 35, 953-964.

van Cuyk S, Siegrist RL, Lowe K, Harvey R (2004) Evaluating microbial purification during soil treatment of wastewater with multicomponent tracer and surrogate tests. Journal of Environmental Quality 33, 316-329.

van Genuchten MT (1980) A closed-form equation for predicting the hydraulic conductivity of unsaturated soils. Soil Science Society of America Journal 44, 892-898.

Verburg K, Bridge BJ, Bristow KL, Keating BA (2001) 'Properties of selected soils in the Gooburrum Moore Park area of Bundaberg.' CSIRO Land and Water, Canberra. Technical Report 9/01, April 2001.

Whitehead JH, Geary PM (2000) Geotechnical aspects of domestic on-site effluent management systems. Australian Journal of Earth Sciences 47, 75-82.

Wilhelm SR, Schiff SL, Robertson WD (1994) Chemical fate and transport in a domestic septic system: unsaturated and saturated zone geochemistry. Environmental Toxicology and Chemistry 13, 193-223. 


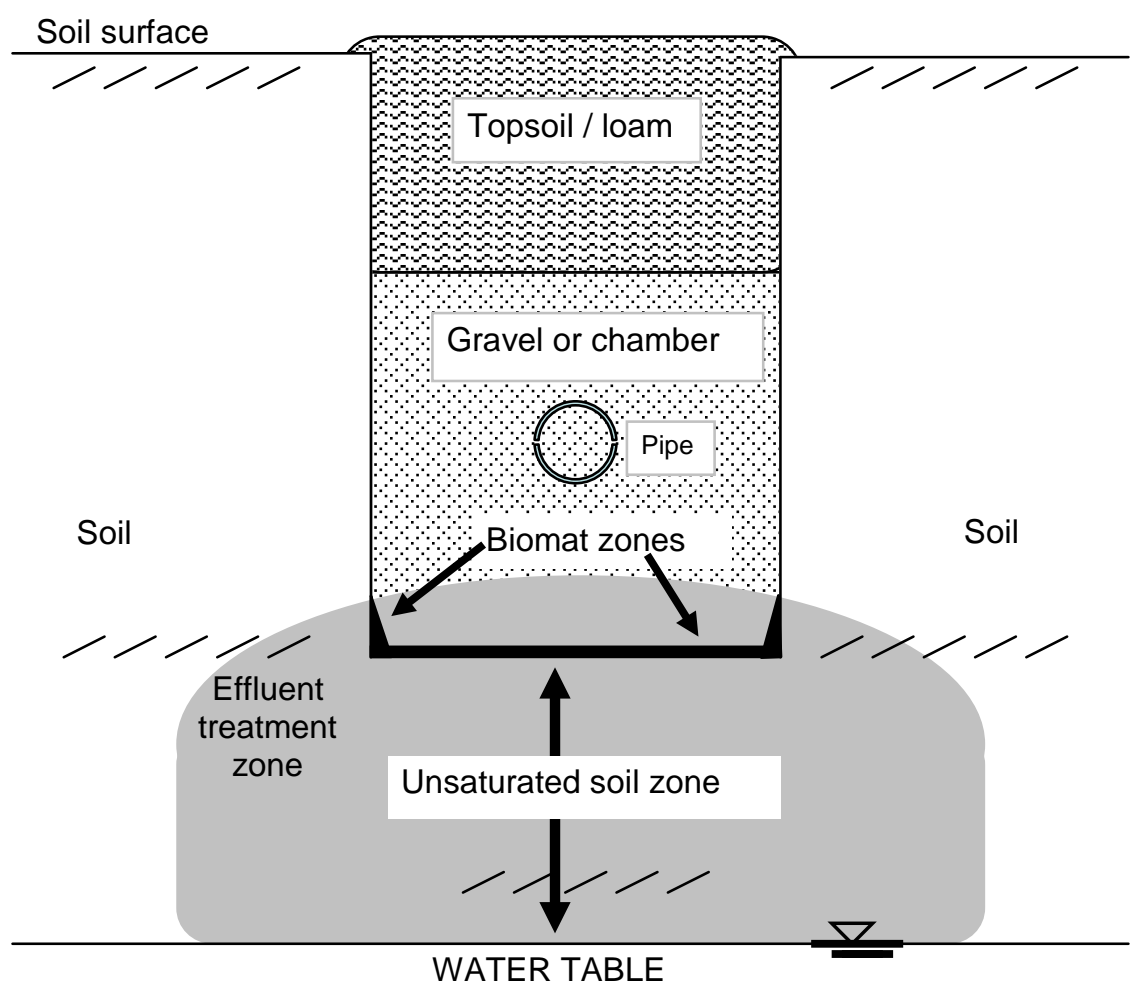

Fig. 1 
Modelling effluent flow in septic systems

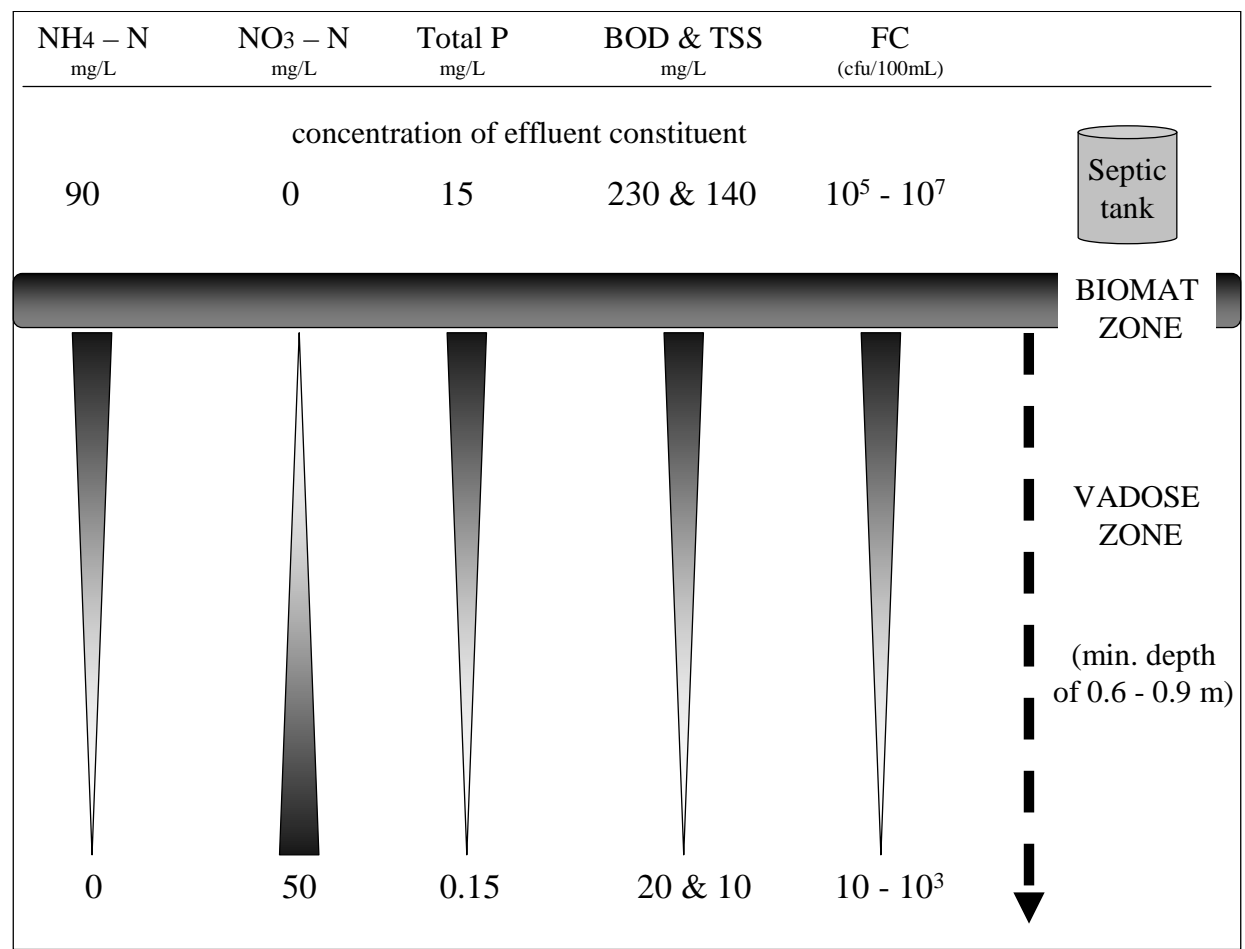

Fig. 2 
Modelling effluent flow in septic systems

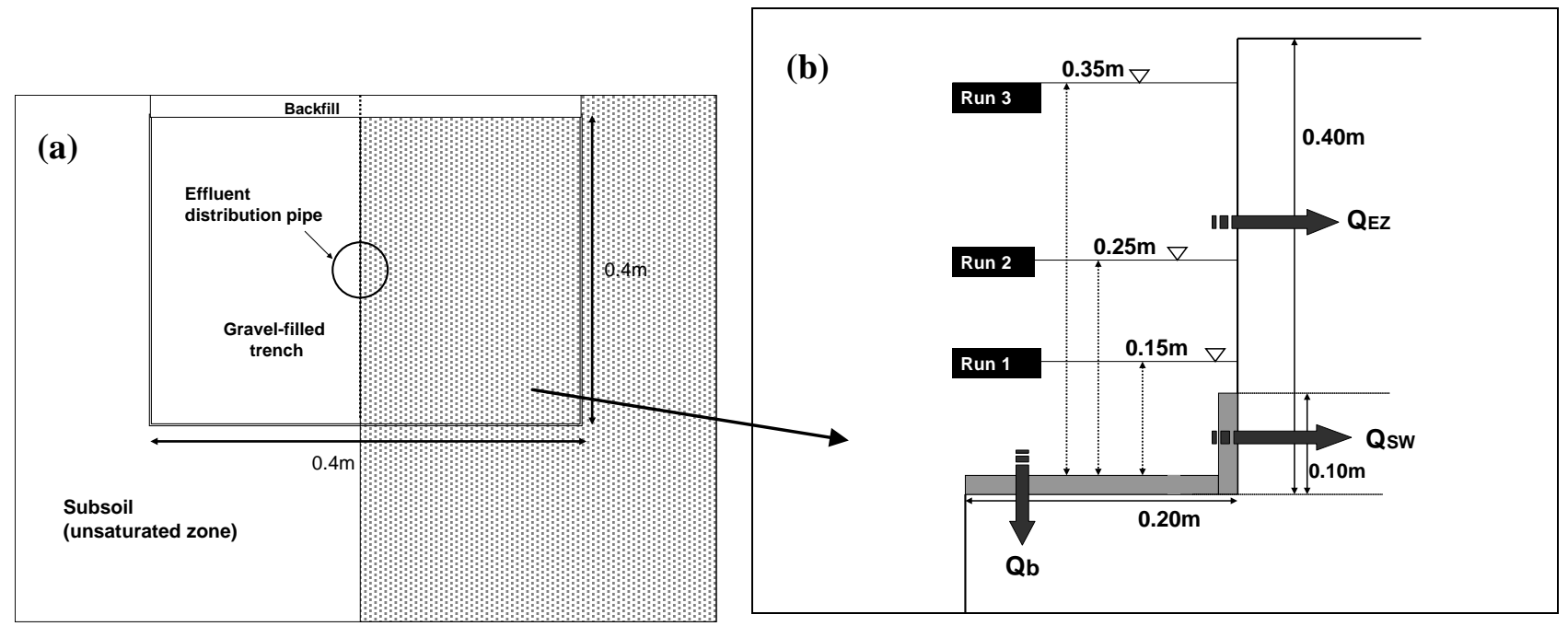

Fig 3 
Modelling effluent flow in septic systems

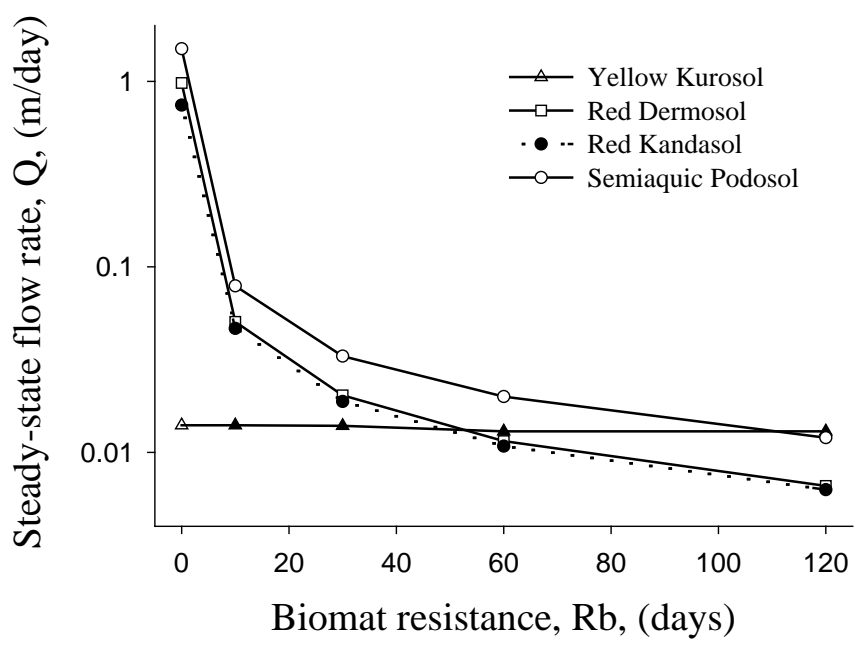

Fig. 4 


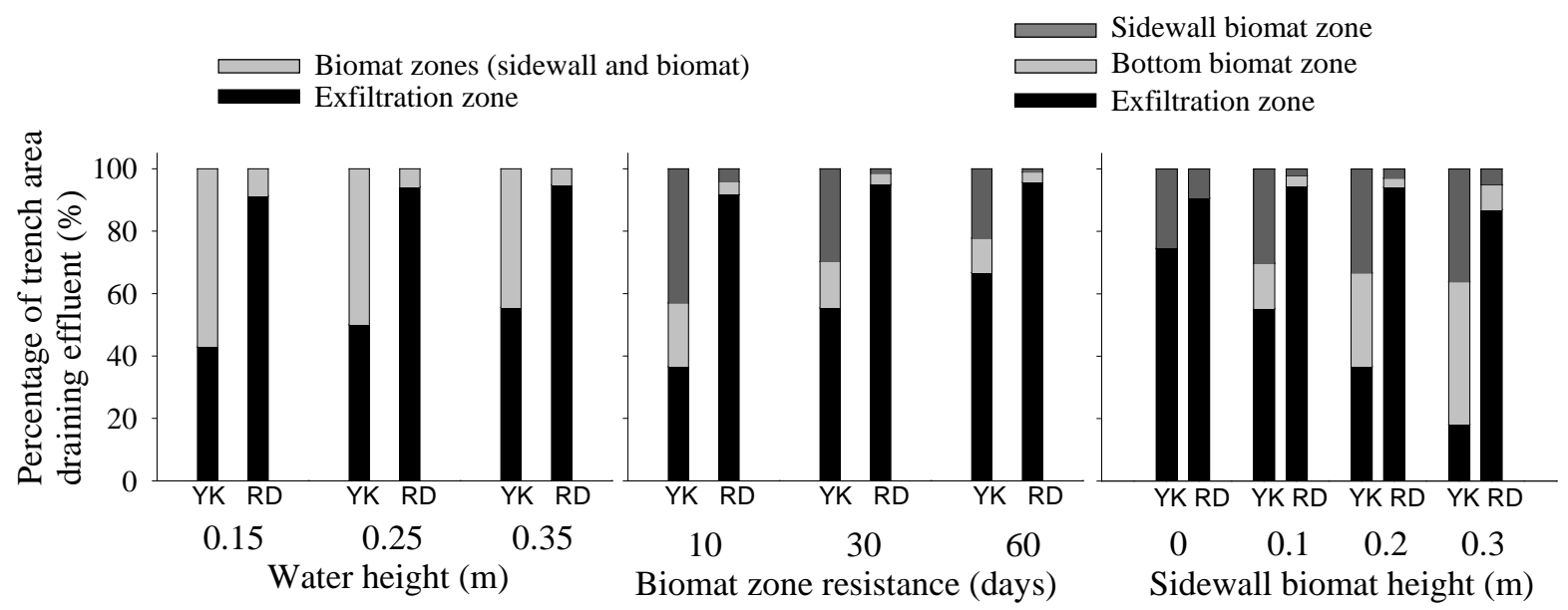

Fig. 5. 


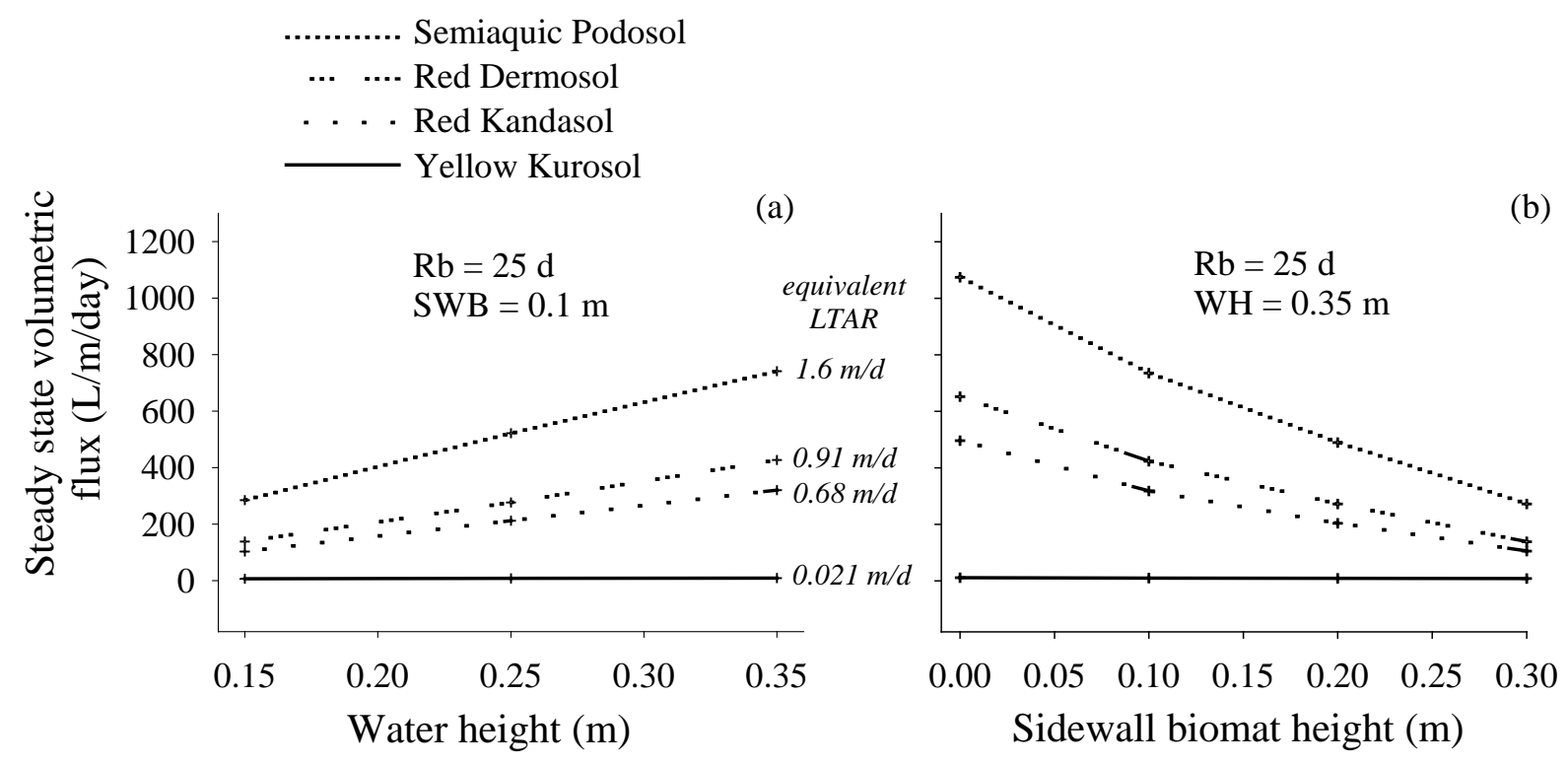

Fig. 6. 

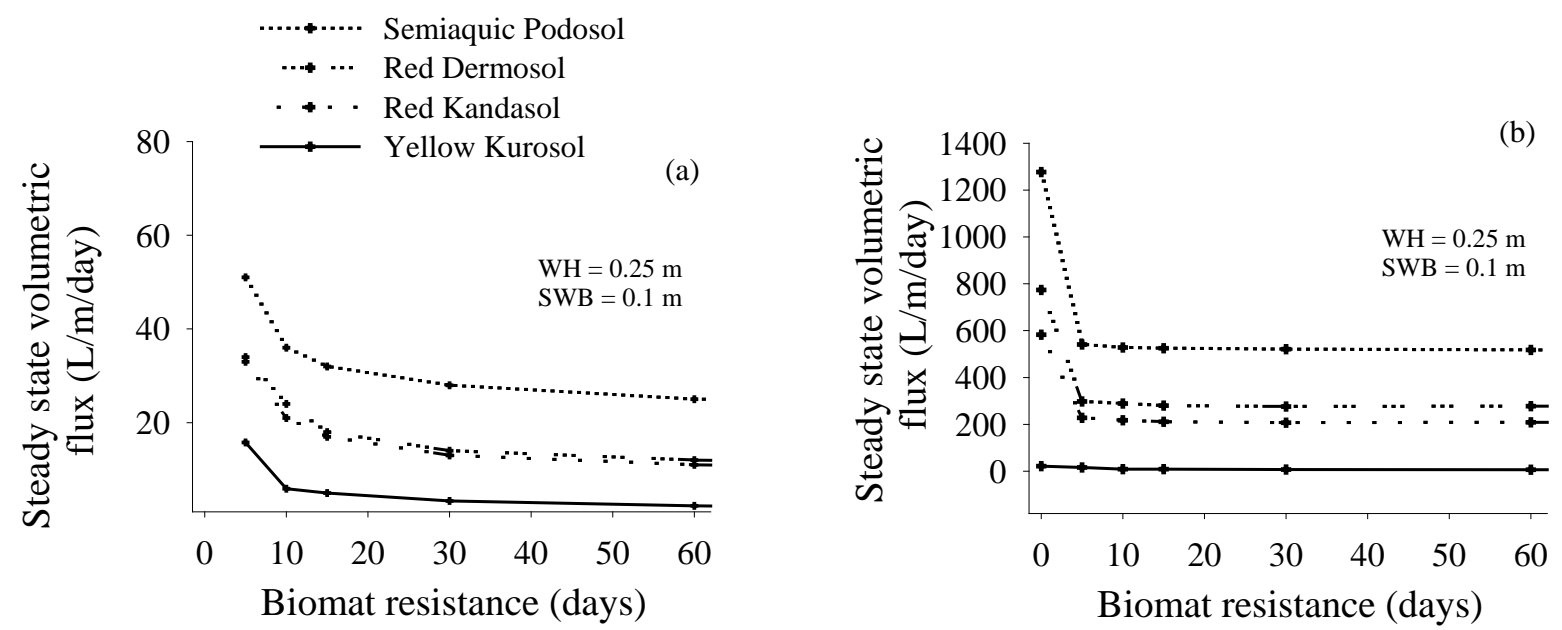

Fig 7 


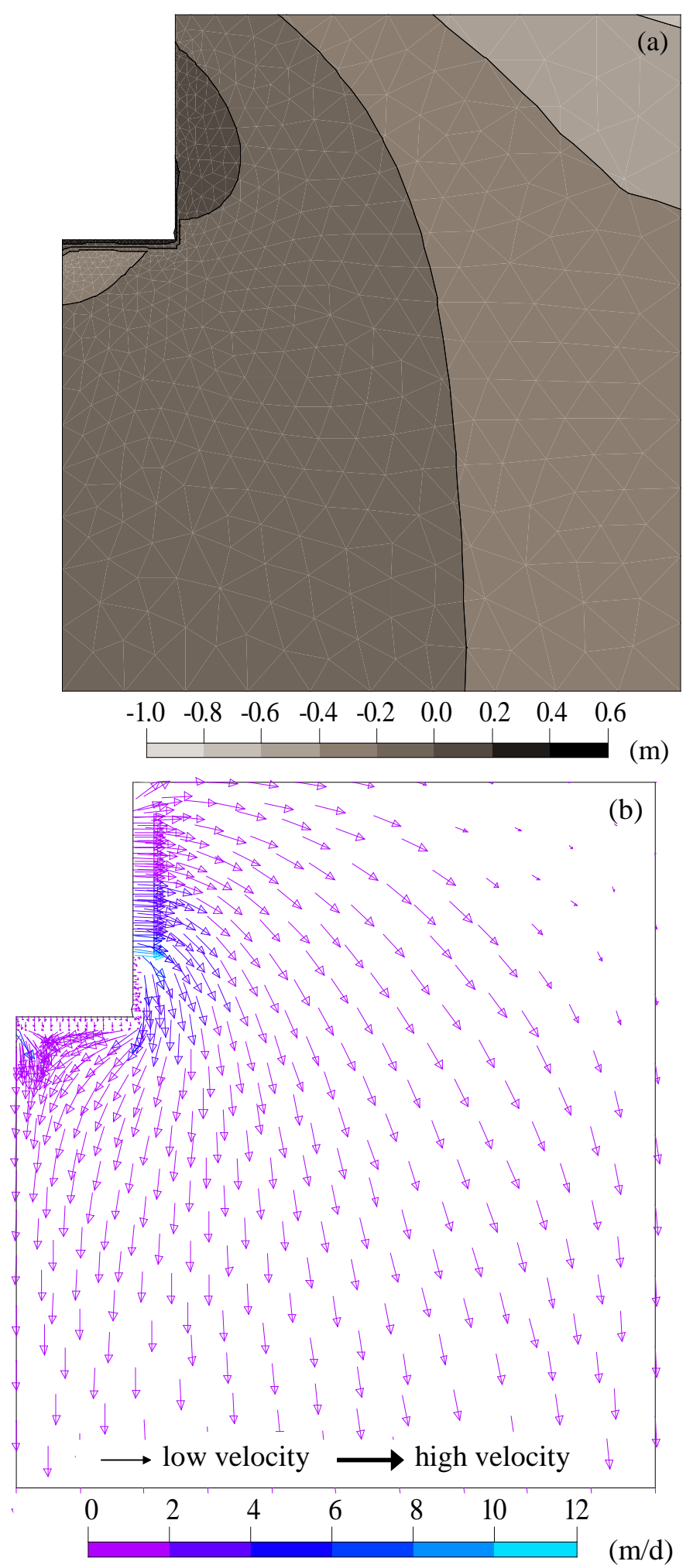

(b)

Fig. 8. 

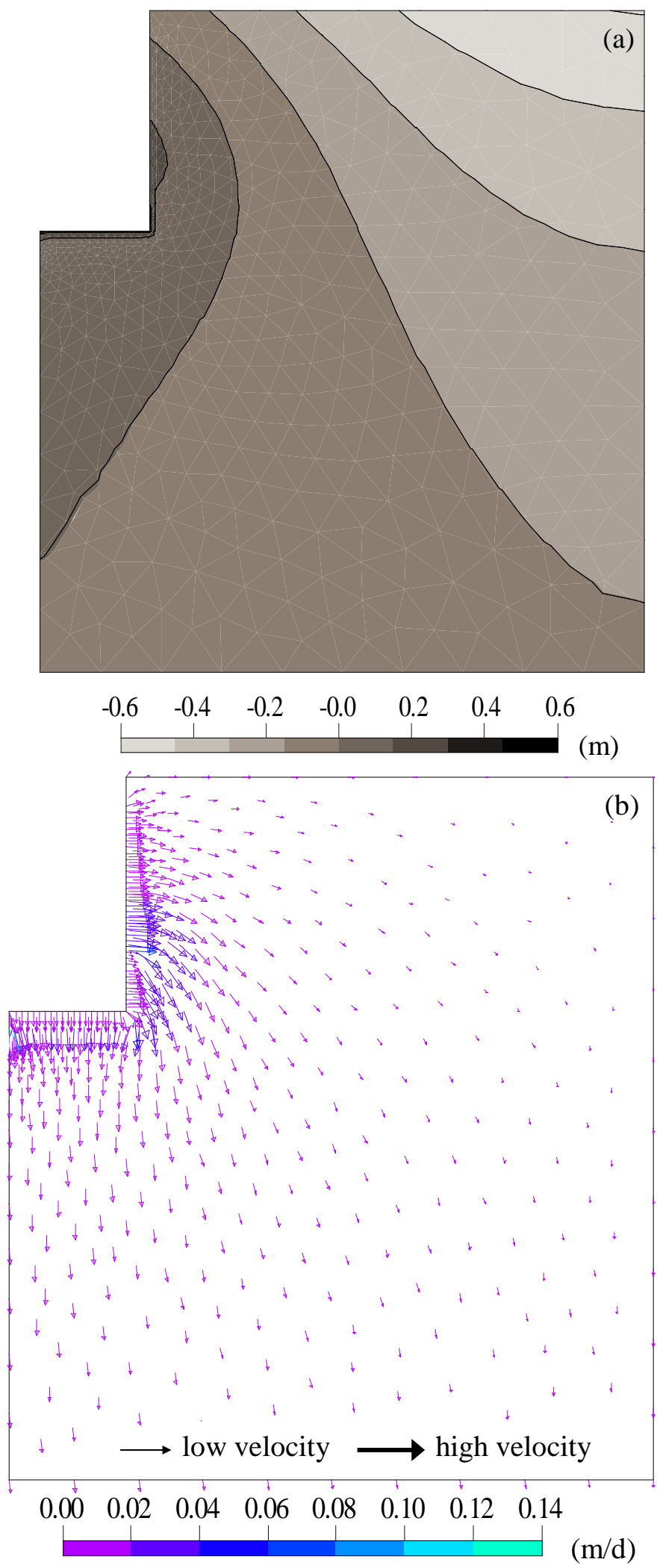

Fig. 9. 
Fig. 1 Key zones of a septic absorption trench where, theoretically, the hydraulically resistant saturated biomat zone creates an unsaturated zone where treatment of effluent pollutants occurs

Fig. 2 Schematic of typical removal efficiency of biomat and unsaturated zone for the main effluent contaminants. The concentrations of septic tank effluent contaminants are shown before (top) and after (bottom) passage through the biomat and unsaturated zone. Data taken from Beal et al. (2005)

Fig 3. (a) Schematic cross-section of a typical of septic trench system where the shaded area is the model domain for all Scenarios (b) Example of trench domain modelled in HYDRUS-2D (Scenario 1)

Fig. 4 Relationship between biomat resistance and steady-state flux calculated using the onedimensional model FLUX

Fig. 5. Percentage of trench area (exfiltration zone and biomat zones) contributing to effluent drainage into surrounding soil for Yellow Kurosol (YK) and Red Dermosol (RD)

Fig. 6. Total volume of effluent infiltrating through trench with (a) increasing water height (WH) and (b) sidewall biomat zone height (SWB) (identical y-axis scale for all plots)

Fig. 7. Total volume of effluent infiltrating with increasing biomat zone resistance $(R b)$ for (a) biomat (sidewall + bottom) only and (b) total trench area (biomats + exfiltration zone) (identical y-axis scale for all plots)

Fig. 8. HYDRUS-2D graphical output from Scenario 1 (water height $0.35 \mathrm{~m}$ ) showing (a) pressure heads and $(b)$ velocity vectors for a Semiaquic Podosol

Fig. 9. HYDRUS-2D graphical output from Scenario 1 (water height $0.35 \mathrm{~m}$ ) showing (a) pressure heads and $(b)$ velocity vectors for a Yellow Kurosol 
Table 1. Summary of some physical properties of soils used in 1D modelling

\begin{tabular}{|c|c|c|c|c|c|c|c|}
\hline Soil type & $\begin{array}{c}\text { Bulk } \\
\text { density }^{\mathrm{A}}\end{array}$ & $\theta$ sat & $\theta_{15}^{\mathrm{B}}$ & sand & silt & clay & $\mathrm{K}_{-0.015}{ }^{\mathrm{C}}$ \\
\hline & $\mathrm{g} / \mathrm{cm}^{3}$ & \multicolumn{2}{|c|}{$\left(\mathrm{cm}^{3} / \mathrm{cm}^{3}\right)$} & \multicolumn{3}{|c|}{ (\% of $<2 \mathrm{~mm}$ fraction) } & $(\mathrm{m} / \mathrm{d})$ \\
\hline $\begin{array}{l}\text { Red Kandasol } \\
\text { (Alifisol, Ultisol) }^{\mathrm{E}}\end{array}$ & 1.75 & 0.36 & 0.18 & 55 & 13 & 32 & 0.74 \\
\hline $\begin{array}{l}\text { Red Dermosol } \\
\text { (Mollisol) }\end{array}$ & 1.71 & 0.27 & 0.06 & 77 & 13 & 10 & 0.98 \\
\hline $\begin{array}{l}\text { Semiaquic Podosol } \\
\text { (Spodosol) } \\
\text { Yellow Kurosol } \\
\text { (Ultisol, Alfisol) }\end{array}$ & 1.66 & 0.19 & 0.10 & 80 & 5 & 15 & 1.51 \\
\hline
\end{tabular}

A In situ analysis

${ }^{\mathrm{B}}$ Volumetric water content at potential of $1500 \mathrm{kPa}$

${ }^{\mathrm{C}}$ Hydraulic conductivity at potential of $-0.015 \mathrm{~m}$

${ }^{\mathrm{D}}$ Australian soil classification (Isbell 1998)

${ }^{\mathrm{E}}$ US Soil Classification (USDA and NRCS 2006) 
Table 2. Input parameters used in SAS modelling

\begin{tabular}{|c|c|c|c|c|c|c|}
\hline Soil type & $\begin{array}{c}\theta \mathrm{r} \\
(\mathrm{m} / \mathrm{m})\end{array}$ & $\begin{array}{c}\theta \mathrm{s} \\
(\mathrm{m} / \mathrm{m})\end{array}$ & $\begin{array}{l}\text { Alpha } \\
(1 / \mathrm{m})\end{array}$ & $\mathrm{n}$ & $\begin{array}{l}K s \\
(\mathrm{~m} / \mathrm{d})\end{array}$ & Sources / references \\
\hline Red Kandasol & 0.0741 & 0.346 & 0.0416 & 2.37 & 0.74 & Verburg et al (2001), (Schaap 2001) \\
\hline Red Dermosol & 0.0318 & 0.330 & 0.0443 & 2.57 & 0.98 & Verburg et al (2001), (Schaap 2001) \\
\hline $\begin{array}{l}\text { Semiaquic Podosol } \\
\text { (SP) }\end{array}$ & 0.0365 & 0.324 & 0.0277 & 2.57 & 1.5 & Verburg et al (2001), (Schaap 2001) \\
\hline Yellow Kurosol & 0.08 & 0.485 & 0.0013 & 1.33 & 0.014 & Talsma (1983) \\
\hline Biomat zone & 0.07 & 0.36 & 0.0033 & 1.5 & $\begin{array}{l}0.02- \\
0.0033\end{array}$ & $\begin{array}{l}\text { Beach and McCray (2003) Magdoff and } \\
\text { Bouma (1974), Bouma (1975) }\end{array}$ \\
\hline
\end{tabular}


Table 3. Biomat properties and ponded trench conditions used in Scenarios 1-3

\begin{tabular}{lcccc}
\hline Scenario & $\begin{array}{c}\mathrm{Rb} \\
(\mathrm{days})\end{array}$ & $\begin{array}{c}\mathrm{Kb} \\
(\mathrm{mm} / \mathrm{d})\end{array}$ & $\begin{array}{c}\text { SW biomat ht. } \\
(\mathrm{m})\end{array}$ & $\begin{array}{c}\text { Water ht. } \\
(\mathrm{m})\end{array}$ \\
\hline $\begin{array}{l}\text { 1 Increasing ponded water height } \\
(\mathrm{WH})\end{array}$ & 25 & 0.8 & 0.10 & $\begin{array}{c}0.15,0.25, \\
0.35\end{array}$ \\
\hline $\begin{array}{l}\text { 2 Increasing biomat resistance } \\
(\mathrm{Rb})\end{array}$ & $\begin{array}{c}0,10, \\
30,60\end{array}$ & $\begin{array}{c}0,2,0.67, \\
0.33\end{array}$ & 0.10 & 0.25 \\
\hline $\begin{array}{l}\text { 3 Increasing sidewall (SW) } \\
\text { biomat }\end{array}$ & 25 & 0.8 & $0,0.10,0.20,0.30$ & 0.35 \\
\hline
\end{tabular}

